Agnieszka Bielak (iD https://orcid.org/0000-0003-4853-1911

Katolicki Uniwersytet Lubelski Jana Pawła II

\title{
Wewnętrzny nurt
}

(Piotr Mitzner, Ludzie z nieludzkiej ziemi. Rosyjski krag Józefa Czapskiego, Państwowy Instytut Wydawniczy, Wydawnictwo Naukowe UKSW, Warszawa 2021, ss. 382)

\section{The Inner Current (Piotr Mitzner, Ludzie z nieludzkiej ziemi. Rosyjski krag Józefa Czapskiego, Państwowy Instytut Wydawniczy, Wydawnictwo Naukowe UKSW, Warszawa 2021, ss. 382)}

To kolejna publikacja Piotra Mitznera zwracająca uwagę na polsko-rosyjskie związki kulturowe i dotycząca rosyjskich wątków w biografii Józefa Czapskiego. Kilka lat temu ukazał się Warszawski „Domek w Kotomnie” (2014), rok później Warszawski krag Dymitra Fitosofowa (2015), do którego to tytułu niniejsza publikacja bezpośrednio nawiązuje. W każdej ze wspomnianych książek pojawia się też główny bohater ostatniej publikacji - Józef Czapski. Również staraniem Mitznera opublikowano dwujęzyczną antologię polskich wierszy wojennych ${ }^{1}$, przygotowaną jeszcze w latach czterdziestych XX wieku w Taszkiencie przez Józefa Czapskiego - żołnierza Armii Andersa pełniącego funkcję kierownika Wydziatu Propagandy II Korpusu.

O tym, jak istotna była kultura rosyjska w formacji Czapskiego, nie trzeba przekonywać nikogo, kto choćby przelotnie zetknął się z jego biografią ${ }^{2}$. Piotr Mitzner gromadzi w najnowszej publikacji bezcenne materiały źródłowe z archiwów francuskich, niemieckich, rosyjskich i amerykańskich obejmujące korespondencję Czapskiego z przyjaciółmi - Rosjanami. Znajdujemy tu także niepublikowane fragmenty dziennika Czapskiego i fragmenty już dostępne, ale dotychczas tylko po rosyjsku, z dziennika Dymitra Fiłosofowa, Anny Achmatowej czy Lidii Czukowskiej. Nie do przecenienia jest praca archiwalna, jaka została wykonana przy przygotowywaniu tej książki.

${ }^{1}$ Polskie wiersze wojenne/ Польская военная поэзия, ułożył J. Czapski, podali do druku I. Biełow, P. Mitzner, Warszawa 2019.

${ }^{2}$ Zob. na przykład T. Sucharski, Józefa Czapskiego na „dobre izte z Rosją" [w:] tegoż, Polskieposzukiwania innej Rosji. O nurcie rosyjskim w literaturze Drugiej Emigracji, Gdańsk 2008, s. 33-83. 
Pierwotnym moim zamiarem - pisze Mitzner we wstępie - była publikacja in extenso znanej mi dziś korespondencji Józefa Czapskiego z Rosjanami, obejmującej lata 1920-1990. Okazało się to niewykonalne z kilku powodów. Po pierwsze, niewątpliwych luk. Rosyjskie listy Czapskiego odnalazłem w archiwach we Francji, w Niemczech, Rosji i Stanach Zjednoczonych, ale jestem przekonany, a nawet mam dowody na to, że sporo ich znajduje się jeszcze w rękach prywatnych. Nie udało mi się ich wydobyć. Niewiele też zachowało się listów przychodzących. Przedwojenne spłonęły i nie wiadomo, co się stało z powojennymi, gdzie podziały się listy Andrieja Siniawskiego, Lidii Czukowskiej, Natalii Gorbaniewskiej, Władimira Maksimowa, Jurija Iwaska do Czapskiego. Miejmy nadzieję, że kiedyś się odnajdą ${ }^{3}$.

Omawiana publikacja nie jest jednak - jak można by wnioskować z dotychczasowego opisu - jedynie zbiorem materiałów źródłowych. Autor włącza bowiem te materiały w fascynującą opowieść o ludziach z „rosyjskiego kręgu” Czapskiego, o trudnych losach polskich i rosyjskich emigrantów ze skomplikowaną historią XX wieku w tle. To także opowieść o Rosji widzianej oczami Czapskiego: „Jego Rosja nie jest uwikłana w zastarzałe resentymenty, lęki ani naiwne fascynacje. Jest przeżyta we własnym doświadczeniu i na własnej skórze"4.

Już dziś można powiedzieć, że Ludzie z nieludzkiej ziemi... stanowią doskonaty punkt wyjścia do dalszych pogłębionych badań, nie tylko nad biografią Czapskiego - głównego bohatera Ludzi z nieludzkiej ziemi, który przyciągał do siebie tak liczne grono niepospolitych indywidualności - ale i nad relacjami między polską i rosyjską kulturą.

W „rosyjskim kręgu” Czapskiego pojawiają się osoby od dawna z nim łączone, jak Dmitrij Mereżkowski, Zinaida Gippius, Dymitr Fiłosofow, Anna Achmatowa czy Aleksiej Remizow, ale też postacie niekoniecznie dotychczas obecne w biografii Czapskiego, na przykład redaktor emigracyjnej „Narodnoj Prawdy” - Roman $\mathrm{Gul}^{5}$, czy Jurij Iwask - wykładowca literatury w Yale i redaktor pisma „Opyty”.

Wśród głównych bohaterów książki szczególne miejsce należy się Fiłosofowowi - mentorowi Józefa i Marii Czapskich, którego rola w formowaniu młodych Czapskich w okresie międzywojnia, mimo że zauważona, nie została jeszcze właściwie opisana. Wzmianki o uwagach Fiłosofowa i odwołania do tego, co powiedział/powiedziałby „Dimka”, będą obecne w dzienniku Czapskiego do ostatnich jego tomów. Był on niewątpliwie osobą, która wywarła ogromny wpływ na Czapskiego, na jego postrzeganie świata, a także - na jego malarstwo. Listy, dziennikowe zapisy i tłumaczenia publikacji zamieszczone przez Mitznera pozwalają odczuć intensywność tej relacji. Wydaje się jednak, że dla jej pełnego rozpoznania

${ }^{3}$ P. Mitzner, Ludzie z nieludzkiejziemi. Rosyjski krag Józefa Czapskiego, Warszawa 2021, s. 11.

${ }^{4}$ Tamże, s. 9.

${ }^{5} \mathrm{O}$ listach J. i M. Czapskich w archiwum Romana Gula w Beinecke Library (Yale) wspomina Jan Zieliński (Szkatutki Newerlego, Warszawa 2012, s. 120). 
konieczna będzie zarówno lektura dziennika Czapskiego w jak najpełniejszej wersji, jak i dziennika Fiłosofowa.

Najwszechstronniej przedstawiona została w książce korespondencja Czapskich z Aleksiejem Remizowem, którego twórczość poznał autor Tumultu $i$ widm jeszcze przez Fiłosofowa, a w latach pięćdziesiątych XX wieku zetknął się z nim osobiście w Paryżu. O fascynacji Czapskiego rosyjskim pisarzem świadczą jego eseje, ale i wiele dziennikowych zapisów. Opublikowane tutaj listy są dowodem bliskiej relacji i włączenia Czapskich do kręgu najbliższych przyjaciół Remizowa.

Znajdujemy tu też wiele pojedynczych, a istotnych listów, jak bardzo poruszający i zawierający deklarację pomocy w imieniu paryskiego Instytutu Literackiego list Czapskiego do Borysa Pasternaka po lekturze Doktora Żywago, a z drugiej strony - poznajemy też reakcje Rosjan po wydaniu przez Czapskiego Na nieludzkiej ziemí.

Poruszająca, ze względu zarówno na okoliczności historyczne, jak i na indywidualne ludzkie losy, jest historia przygotowywania przez Czapskiego w Taszkiencie wspomnianej na wstępie antologii polskiej poezji. Spotkanie z reprezentującym ówczesną władzę Aleksym Tołstojem, jak również z poszukującą informacji o aresztowanym synu Anną Achmatową jest jedynie drobnym sygnałem napięć, jakie towarzyszyły tej pracy.

Na postawę Czapskiego wobec Rosjan niewątpliwie miała wpływ lektura listów Norwida, któremu zresztą poświęcony jest osobny rozdział publikacji, i takie między innymi zdanie autora Promethidiona cytowane przez Mitznera: „Jeżeli Polacy nie mają i nie chcą uprawiać zdolności podniesienia nieprzyjaciół Ojczyzny do godności znośnych sąsiadów, to wszystko na nic się nie zda”

Trzeba przy tym zaznaczyć, że otwartość, także wobec nieprzyjaciól, od zawsze cechowała Czapskiego, który już w 1918 roku, poszukując zaginionych kolegów z 1. Pułku Ułanów Krechowieckich (jak się okazało rozstrzelanych już wówczas przez bolszewików), potrafił docenić ideowe zaangażowanie Jeleny Stasowej (nazywanej „sumieniem rewolucji”), z którą jednocześnie ideowo zupełnie się nie zgadzał. Norwid jedynie umocnił tę osobistą predylekcję, wyraźnie widoczną we wspomnieniu spotkania:

Zrobiła na mnie dobre wrażenie. Okulary w żelaznej oprawce, przetarte łokcie, skromnie ubrana, twarz sympatyczna i uczciwa. Powiedziałem jej o swych poszukiwaniach. Pomyślała kilka sekund i mówi:

- Pomogę panu.

${ }^{6}$ Recenzja Niny Berberowej: O knigie „Biesczetowieczaja ziemlia” J. Czapskiego [w:] P. Mitzner, dz. cyt., s. 193-196.

${ }^{7}$ C. Norwid do K. Ruprechta, IX-X 1863 [w:] Pisma wszystkie, zebrał, tekst ustalił i uwagami krytycznymi opatrzył J.W. Gomulicki, Warszawa 1971, t. 9, s. 114. 
- to był jedyny raz w Rosji Sowieckiej (a potem także poszukiwałem poległych albo zaginionych bez wieści oficerów), że ktoś zwrócił się do mnie - jakby to powiedzieć? - po chrześcijańsku, albo po prostu po ludzku .

Ponad pół wieku później, w relacji z konferencji prasowej Aleksandra Sołżenicyna w Zurychu (15 listopada 1974 roku), Czapski zwraca uwagę na podkreślanie przez autora Archipelagu Gutag siły chrześcijaństwa w walce ze złem:

Akcent tu był przede wszystkim położony na stronę chrześcijańską, religijną w najszerszym znaczeniu tego słowa - religii jako źródła siły, gotowości ofiary, wyrzeczeń, całkowitego oddania się sprawie, do śmierci włącznie. Te wielkie słowa, tak przez tyle przemówień zdarte, brzmiały w ustach mówcy jakby były powiedziane po raz pierwszy z całą siłą pełnego przeżycia9

Jednocześnie zaznacza Czapski różnice między propozycją Sołżenicyna i myślą tak przecież kiedyś mu bliską - Lwa Tołstoja:

Co łączy i co dzieli Sołżenicyna od Tołstoja powinno być przemyślane do końca. Tołstoj (...) głęboko Rosjan i nie tylko Rosjan naznaczył. Wyznawcy jego, nieprotiwlency [niesprzeciwiający się siłą złu - A.B.], których obowiązywało przede wszystkim jedno: „nie zabijać” - było ich tysiące, iluż tkwiło w więzieniach carskich? Czy uratowała ojczyznę ta garść czystych?

I tu zdaje mi się, że między Sołżenicynem i Tołstojem nie ma jedności: ten człowiek walki wydaje mi się nieskończenie mniej dogmatyczny i mniej sztywny niż Tołstoj - starzec, głoszący niesprzeciwianie się złu jako prawie że jedyną wskazówkę. Sołżenicyn rozumie, czuje głębiej więzły sprzeczności, w których się człowiek boryka, warstwy i warstwy świadomości i konieczności historycznych, w których człowiek - chcący żyć społecznie, żyć musi ${ }^{10}$.

Czapski był niewątpliwie człowiekiem żyjącym społecznie i głęboko rozumiejącym konieczności historyczne. Najgłębszy nurt jego wewnętrznego życia nie został jednak nigdy zmącony, mimo że los nie oszczędził mu najtrudniejszych doświadczeń. Zarówno jako dwudziestokilkuletni młodzieniec w roku 1918, jak i jako doświadczony życiem osiemdziesięciolatek piszący o Sołżenicynie - w każdym, kogo spotyka, stara się dostrzec przede wszystkim człowieka. Ostatecznie nigdy nie wygasło w nim młodzieńcze pragnienie chrześcijańskiej ogólnoświatowej

${ }^{8}$ Pietrograd, 1917 god. Rasskazywajet Juzef Czapskij, zapisała M. Wiernikowskaja, „Russkaja mysl'” 1987, nr 3702 [w:] P. Mitzner, dz. cyt., s. 23-24. Tę samą sytuację nieco innymi słowami wspomina Czapski w Na nieludzkiej ziemi (zob. wyd. Kraków 2017, s. 177-178).

${ }^{9}$ J. Czapski, Sotżenicyn [w:] P. Mitzner, dz. cyt., s. 303-304. Prwdr. „Kultura” 1974, nr 12.

${ }^{10}$ Tamże, s. 305. 
rewolucji, czy te $\dot{z}$ - jaki pisała Maria Janion - pragnienie „przemienienia” człowieka ${ }^{11}$ - choć oczywiście pragnienie to dojrzewało i ulegało przekształceniu pod wpływem historycznych doświadczeń.

W pośmiertnym wspomnieniu o Czapskim pióra kolejnego przyjaciela Rosjanina, Michała Hellera, czytamy:

Józef Czapski doświadczył wszystkiego, czym mógł człowieka uraczyć XX wiek: rewolucji, wojen, więzienia, obozów, wygnania. (...)

Nie było w nim zła ani okrucieństwa, ani nienawiści. Kilka lat temu Andrzej Wajda nakręcił film o Czapskim. Między innymi pytał o Katyń. Józef opowiadał o życiu w obozie. Nagle powiedział, że wolałby mówić po rosyjsku. Pytania więc zacząłem zadawać ja, a on odpowiadał swoją niezwykłą ruszczyzną, jakiej nikt dziś już nie pamięta. Po nagraniu spytałem go, czy trudno mu mówić językiem strażników i katów. Nie. Rosyjski nie był dla niego językiem strażników i katów, był językiem Tołstoja i Dostojewskiego, Rozanowa i Mereżkowskiego, Achmatowej i Sołżenicyna... ${ }^{12}$

Może dlatego potrafił rozmawiać z każdym i może dlatego jemu powierzał Giedroyc szczególnie ważne misje. Z Rosyjskiego kręgu Józefa Czapskiego dowiadujemy się między innymi o szczegółach zakreślonej na szerszą skalę działalności politycznej paryskiej „Kultury”, jak o spotkaniu Giedroycia z Aleksandrem Kiereńskim, byłym premierem Rządu Tymczasowego, w listopadzie 1949 roku w Paryżu, które miało być początkiem „większej układanki polsko-rosyjskiej” (określenie Jerzego Giedroycia). W tej sprawie miał się z nim spotkać Czapski rok później podczas wizyty w USA.

To tylko wybrane "wglądy” w przebogatą materię Ludzi z nieludzkiej ziemi, książki, z którą trzeba zapoznać się dogłębnie, którą warto przestudiować. Nie wspomniałam o Gorbaniewskiej, Liebiediewej, Siniawskim i wielu innych istotnych bohaterach tej publikacji i historii XX wieku. Rosyjski krag Józefa Czapskiego to w istocie tysiące powiązanych ze sobą ludzkich losów, a każdy z nich jest materiałem na osobną opowieść. Każda przywołana osoba otwiera tu bowiem nie tylko indywidualną historię, ale kolejny „krąg” ludzi dobrej woli, ludzi, których łączył najgłębszy wewnętrzny nurt - pragnienie tworzenia „ludzkiej” rzeczywistości.

${ }^{11}$ M. Janion, Artysta przemienienia [w:] tejże, Projekt krytyki fantazmatycznej. Szkice o egzystencjach ludzi i duchów, Warszawa 1991, s. 189-209.

${ }^{12}$ M. Heller, Cztowiek przesztości i przysztości [w:] P. Mitzner, dz. cyt., s. 331-332. 